\title{
https://doi.org/10.46813/2020-130-047 \\ NUMERICAL SIMULATION OF PLATEAU FORMATION BY AN ELECTRON BUNCH ON THE DISTRIBUTION OF AN ACCELERATING WAKEFIELD IN A PLASMA
}

\author{
V.I. Maslov ${ }^{1,2}$, R.T. Ovsiannikov ${ }^{1}$, N. Delerue ${ }^{3}$, V. Kubytskyi ${ }^{3}$, I.P. Levchuk ${ }^{2}$, \\ I.N. Onishchenko ${ }^{2}$ \\ ${ }^{I}$ V.N. Karazin Kharkiv National University, Kharkiv, Ukraine; \\ ${ }^{2}$ National Science Center "Kharkov Institute of Physics and Technology", Kharkiv, Ukraine; \\ ${ }^{3}$ LAL, Univ. Paris-Saclay, CNRS/IN2P3, Orsay, France
}

\section{E-mail:vmaslov@kipt.kharkov.ua}

Over the past decade the production of multi-gigaelectrons from laser-driven and electron-bunch-driven plasma accelerators has been successfully demonstrated. However, applications require improvements of accelerated bunch size and its energy spread. One promising candidate to satisfy these requirements is to externally inject an electron bunch into an electron-bunch-driven plasma accelerator. We present studies on the optimization of the self-consistent distribution of an accelerating wakefield of plateau type, which can lead to improvement of final quality of the externally injected and accelerated electron bunch, using simulations with the particle-in-cell code LCODE. We quantified the effect of the injected bunch density on the plateau formation in the blowout regime.

PACS: 29.17.+w; 41.75.Lx

\section{INTRODUCTION}

Plasma wakefield accelerators have the ability to sustain accelerating gradients to $100 \mathrm{GV} / \mathrm{m}[1,2]$. In conventional accelerators, due to breakdown which occurs on the walls of the accelerating structure at high electric fields, accelerating gradients are currently limited to approximately $100 \mathrm{MV} / \mathrm{m}$ [3] due to breakdown. Successful experiments on electronbunch-driven wakefield acceleration have demonstrated acceleration of $\mathrm{GeV}$-class electrons [2] and have therefore confirmed the relevance of this acceleration method. Because the plasma accelerators provide large accelerating gradients the plasma [4-21] accelerators are intensively investigated.

However, the quality of electron bunch produced in plasma accelerators is not yet sufficient for the realization applications. Precise control over the injected electron bunch properties is a key problem for plasma wakefield accelerators. One promising strategy towards the improvement of final quality of the accelerated electron bunch is the use of an electron beam from a conventional electron linac. Welldeveloped technologies of radio-frequency linacs allow electron bunches of good quality: small size and small energy spread to be provided.

It has been proposed to use the beam loading effect $[18$, 19] to compensate the energy spread of an electron beam in plasma wakefield accelerators.

In this paper, we report on numerical investigations on optimization of the self-consistent distribution of an accelerating wakefield of plateau type, which can lead to minimizing the bunch quality degradation during acceleration by an electron-bunch-driven plasma wakefield accelerator with external injection. By analyzing the dependence of distribution of an accelerating wakefield on accelerated bunch density in the blowout regime, we have found a mechanism to compensate the energy spread.

We present results of numerical simulation of plasma wakefield excitation in blowout regime by a driver-bunch and of wakefield modification by witness-bunch, made with $2.5 \mathrm{D}$ code LCODE [22] that treats plasma electrons and bunches as ensembles of macro-particles. We consider the bunch, electrons in which are distributed according to Gaussian in the transverse direction along the radius. We use the cylindrical coordinate system ( $r, z)$ and draw the plasma and beam densities and longitudinal electric field at some $\mathrm{z}$ as a function of the dimensionless time $\tau=\omega_{\mathrm{p}} \mathrm{t}$ or $\xi=\mathrm{V}_{\mathrm{b}} \mathrm{t}-\mathrm{z}, \mathrm{V}_{\mathrm{b}}$ is the bunch velocity. Time is normalized on electron plasma frequency $\omega_{\mathrm{pe}}{ }^{-1}$, distance - on c/ $\omega_{\mathrm{pe}}$, bunch current $\mathrm{I}_{\mathrm{b}}-$ on $\mathrm{I}_{\mathrm{cr}}=\pi \mathrm{mc}^{3} / 4 \mathrm{e}$, fields - on $m c \omega_{\mathrm{pe}} / \mathrm{e}$. e, $\mathrm{m}$ are the charge and mass of the electron, $\mathrm{c}$ is the light velocity.

\section{INVESTIGATION OF THE PLATEAU FORMATION ON THE DISTRIBUTION OF AN ACCELERATING WAKEFIELD IN A PLASMA BY AN ELECTRON BUNCH}

To begin with, we consider the wakefield excitation in plasma in blowout regime by short electron bunch (Fig. 1).

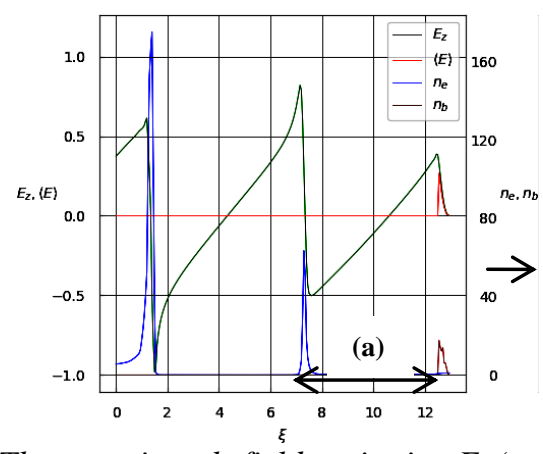

Fig. 1. The on-axis wakefield excitation $E_{z}$ (green line) by electron bunch-driver. The mean field $E_{0}$ is shown to be red as a function of the coordinate $\xi$ along the plasma. Density of bunch-driver $n_{b}$ on the axis is shown by red. Plasma electron density is shown by blue. The

length of uniform bunch-driver is equal to 0.08 of bubble length. The maximum current of bunch-driver is equal to $I_{b}=12.24 \mathrm{kA}$. The direction of movement of the bunch-driver is shown by a one-way arrow. The area (a) of 1 st bubble is shown by a double-headed arrow 
One can see that the electrons have not completely left bubble (see the distribution of plasma electron density $\mathrm{n}_{\mathrm{e}}(\xi)$ in region (a) in Fig. 1, $\left.\xi=\mathrm{z}-\mathrm{V}_{\mathrm{b}} \mathrm{t}\right)$. However, this case is good because on the acceleration interval, a linear longitudinal distribution of the accelerating wakefield $\mathrm{E}_{\mathrm{z}}(\xi)$ is observed. Then, if we achieve the formation of a plateau on $\mathrm{E}_{\mathrm{z}}(\xi)$ at some point $\xi$, then the plateau will be maintained at all points $\xi$ in the process of witness acceleration and its shift inside the bubble. Indeed, in Fig. 2 one can see that witness-bunch of a certain charge leads to the formation of a plateau at $\mathrm{E}_{\mathrm{z}}(\xi)$ at the bubble periphery. It also leads to the formation of a plateau on $E_{z}(\xi)$ at its shift inside the bubble (Figs. 3, 4)

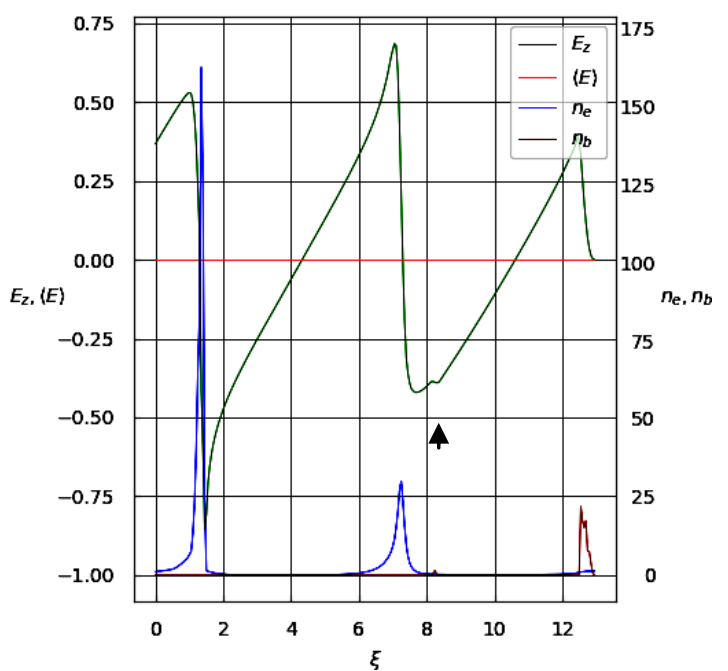

Fig. 2. The on-axis wakefield excitation $E_{z}$ by bunchdriver and plateau formation on $E_{z}(\xi)$ by bunch-witness, $\xi=z-V_{b} t$. Densities of bunches $n_{b}$ on the axis are shown by red. Plasma electron density is shown to be blue as a function of the coordinate $\xi$ along the plasma. The parameters are the same as in Fig. 1. The maximum current of bunch-witness is equal to $I_{b}=1.0 \mathrm{kA}$. The arrow shows the plateau

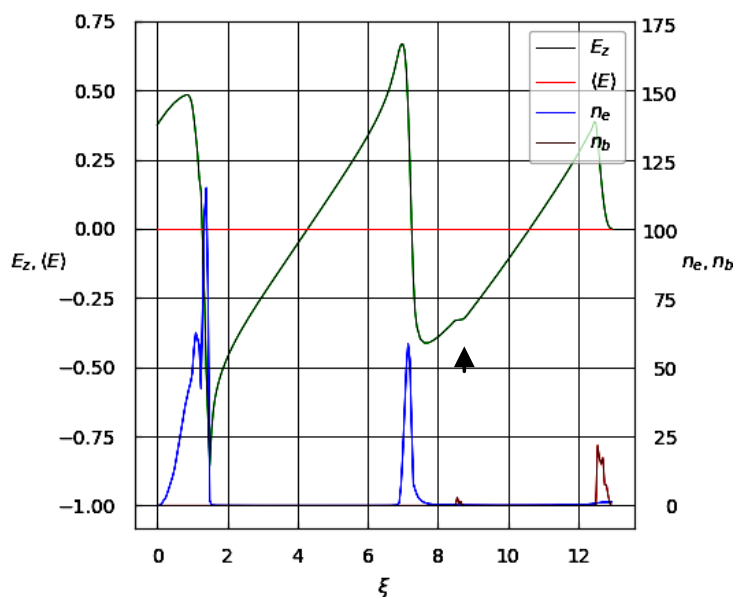

Fig. 3. The on-axis wakefield excitation $E_{z}$ by bunchdriver and plateau formation on $E_{z}(\xi)$ by bunch-witness. Densities of bunches $n_{b}$ on the axis are shown by red.

Plasma electron density is shown to be blue. The parameters are the same as in Figs. 1, 2. The arrow shows the plateau

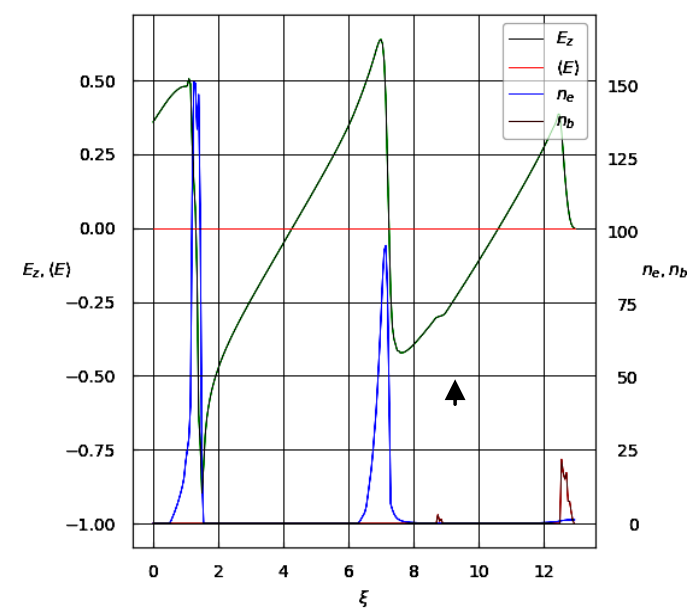

Fig. 4. The on-axis wakefield excitation $E_{z}$ by bunchdriver and plateau formation on $E_{z}(\xi)$ by bunch-witness. Densities of bunches $n_{b}$ on the axis are shown by red.

Plasma electron density is shown to be blue. The parameters are the same as in Figs. 1, 2. The arrow shows the plateau

\section{CONCLUSIONS}

The evolution of the distribution of an accelerating wakefield of plateau type has been investigated during acceleration through bubble in blowout regime by an electron-bunch-driven plasma wakefield accelerator using 2.5D PIC simulations by LCODE. The final quality of the accelerated bunch strongly depends on the distribution of an accelerating wakefield. The investigations presented here show that the accelerated bunch density and its shape can support plateau type distribution of an accelerating wakefield during acceleration through bubble in blowout regime. This can lead to energy spread decrease.

\section{ACKNOWLEDGEMENTS}

This work is supported by National Research Fund of Ukraine "Support for research of leading and young scientists" grant "Transport of electron/positron bunches at high-gradient acceleration by electromagnetic fields excited in dielectric structures or plasma by a high power electron bunches and an intense laser pulse" 2020.02/0299.

\section{REFERENCES}

1. A.J. Gonsalves, K. Nakamura, J. Daniels, et al. Petawatt Laser Guiding and Electron Beam Acceleration to $8 \mathrm{GeV}$ in a Laser-Heated Capillary Discharge Waveguide // Phys. Rev. Lett. 2019, v. 122, p. 084801. 2. I. Blumenfeld, C.E. Clayton, F.-J. Decker, et al. Enery doubling of $42 \mathrm{GeV}$ electrons in a metre-scale plasma wakefield accelerator // Nature Letters. 2007, v. 445, p. 741-744.

3. E. Esarey, C.B. Schroeder, W.P. Leemans. Physics of laser-driven plasma-based electron accelerators // Rev. Mod. Phys. 2009, v. 81, p. 1229-1285.

4. V.I. Maslov, I.N. Onishchenko, I.P. Yarovaya. Plasma Wakefield Excitation, Possessing of Homogeneous Focusing of Electron Bunches // Problems of Atomic Science and Technology. Series «Plasma Physics». 2013, № 1, p. 134-136.

5. V.I. Maslov, I.N. Onishchenko, I.P. Yarovaya. Fields excited and providing a uniform focusing of short 
relativistic electron bunches in plasma // East European Journal of Physics. 2014, v. 1, № 2, p. 92-95.

6. K.V. Lotov, V.I. Maslov, I.N. Onishchenko, et al. Transformer Ratio at Interaction of Long Sequence of Electron Bunches with Plasma // Problems of Atomic Science and Technology. Series «Plasma Physics». 2011, № 3, p. 87-91.

7. V.I. Maslov, I.N. Onishchenko, I.P. Yarovaya. Transformer Ratio at Excitation of Nonlinear Wakefield in Plasma by Shaped Sequence of Electron Bunches with Linear Growth of Charge // Problems of Atomic Science and Technology. Series «Plasma Physics». 2012, № 4, p. 128-130.

8. K.V. Lotov, V.I. Maslov, I.N. Onishchenko Transformer Ratio in Wake-Field Method of Acceleration for Sequence of Relativistic Electron Bunches // Problems of Atomic Science and Technology. Series «Plasma Physics». 2010, № 4, p. 85-89.

9. V.I. Maslov, I.N. Onishchenko, I.P. Yarovaya. Wakefield Excitation in Plasma by Sequence of Shaped Electron Bunches // Problems of Atomic Science and Technology. Series «Plasma Physics». 2012, № 6, p. 161-163.

10. I.P. Levchuk, V.I. Maslov, I.N. Onishchenko. Transformer Ratio at Wakefield Excitation by Linearly Shaped Sequence of Short Relativistic Electron Bunches // Problems of Atomic Science and Technology. Series «Plasma Physics». 2015, № 6, p. 37-41.

11. K.V. Lotov, V.I. Maslov, I.N. Onishchenko, et al. Mechanisms of Synchronization of Relativistic Electron Bunches at Wakefield Excitation in Plasma // Problems of Atomic Science and Technology. Series «Plasma Physics». 2013, № 4, p. 73-76.

12. I.Y. Kostyukov, A.M. Pukhov. Plasma-based methods for electron acceleration: current status and prospects // Phys. Usp. 2015, v. 58 (1), p. 81.

13. J. Thomas, I.Yu. Kostyukov, J. Pronold, A. Golovanov, A. Pukhov. Non-linear theory of a cavitated plasma wake in a plasma channel for special applications and control // Phys. Plasm. 2016, v. 23, p. 053108.

14. T. Tajima, J.M. Dawson. Laser Electron Accelerator // Phys. Rev. Lett. 1979, v. 43, p. 267.

15. T. Tajima, K. Nakajima, G. Mourou. Laser Acceleration // Rivista del Nuovo Cimento. 2017, v. 40, p. 33.

16. N.I. Ayzatsky, A.N. Dovbnya, V.A. Kushnir, et al. Electron resonant high-current accelerator for research of collective acceleration methods // Plasma Phys. 1994, v. 20, № 7,8, p. 671-673.

17. A.V. Kirichok, V.M. Kuklin, A.V. Mischin, et al. Modelling of Superradiation Processes Driven by an UltraShort Bunch of Charged Particles Moving through a Plasma // Problems of Atomic Science and Technology. Series «Plasma Physics». 2015, № 4(98), p. 255-257.

18. S. Romeo, M. Ferrario, A.R. Rossi. Beam loading assisted matching scheme for high quality plasma acceleration in linear regime // Phys. Rev. Accel. Beams. 2020 , v. 23, p. 071301.

19. T. Katsouleas, S. Wilks, P. Chen, T.J.M. Dawson, J.J. Su. Beam Loading in Plasma Accelerators // Particle Accelerators. 1987, v. 22, p. 81-99.

20. S.S. Baturin, A. Zholents. Upper limit for the accelerating gradient in the collinear wakefield accelerator as a function of the transformer ratio // Phys. Rev. Accel. Beams. 2017, v. 20, p. 061302.

21. R.J. Shalloo, C. Arran, L. Corner, et al. Hydrodynamic optical-field-ionized plasma channels // Phys. Rev. E. 2018, v. 97, p. 053203.

22. A.P. Sosedkin, K.V. Lotov. LCODE: A parallel quasistatic code for computationally heavy problems of plasma wakefield acceleration // Nucl. Instr. and Meth. in Phys. Res. A. 2016, v. 829, p. 350-352.

Article received 12.10.2020

\section{ЧИСЛЕННОЕ МОДЕЛИРОВАНИЕ ФОРМИРОВАНИЯ ПЛАТО ЭЛЕКТРОННЫМ СГУСТКОМ НА РАСПРЕДЕЛЕНИИ УСКОРЯЮЩЕГО КИЛЬВАТЕРНОГО ПОЛЯ В ПЛАЗМЕ}

\section{В.И. Маслов, Р.Т. Овсянников, N. Delerue, V. Kubytskyi, И.П. Левчук, И.Н. Онищенко}

За последнее десятилетие было успешно продемонстрировано получение электронов с энергией несколько гигаэлектронвольт в плазменных ускорителях с лазерным импульсом и электронным сгустком. Однако приложения требуют улучшения размера ускоряемого сгустка и его энергетического разброса. Одним из многообещающих кандидатов для удовлетворения этих требований является инжекция электронного сгустка извне в плазменный ускоритель, управляемый электронным сгустком. Мы представляем исследования по оптимизации самосогласованного распределения ускоряющего кильватерного поля типа плато, которое может привести к улучшению конечного качества внешне инжектируемого и ускоренного электронного сгустка, с использованием моделирования при помощи PIC-кода LCODE. Мы количественно оценили влияние плотности инжектированного сгустка на формирование плато в нелинейном режиме опрокидывания.

\section{ЧИСЛОВЕ МОДЕЛЮВАННЯ ФОРМУВАННЯ ПЛАТО ЕЛЕКТРОННИМ ЗГУСТКОМ НА РОЗПОДІЛ ПРИСКОРЮЮЧОГО КІЛЬВАТЕРНОГО ПОЛЯ В ПЛАЗМІ}

\section{В.I. Маслов, Р.Т. Овсянников, N. Delerue, V. Kubytskyi, І.П. Левчук, І.Н. Онищенко}

За останнє десятиліття було успішно продемонстровано отримання електронів 3 енергією декілька гігаелектронвольт у плазмових прискорювачах з лазерним імпульсом і електронним згустком. Однак застосування вимагають поліпшення розміру згустку, що прискорюється, і його енергетичного розкиду. Одним 3 перспективних кандидатів для задоволення цих вимог є інжекція електронного згустку ззовні в плазмовий прискорювач, керований електронним згустком. Ми представляємо дослідження з оптимізації самоузгодженого розподілу прискорюючого кільватерного поля типу плато, яке може привести до поліпшення кінцевої якості зовні інжектованого і прискореного електронного згустку, з використанням моделювання за допомогою PIC-коду LCODE. Ми кількісно оцінили вплив щільності інжектованого згустку на формування плато в нелінійному режимі перекидання. 